\title{
A STUDY OF LIVER DISORDER IN ULCERATIVE COLITIS
}

\author{
B. N. Brooke, M.D., M.CHIR., F.R.C.S. \\ Reader in Surgery, University of Birmingham \\ P. W. Dykes, M.B., Ch.B.(N.Z.), M.R.C.P., M.R.A.C.P. \\ Lecturer in Experimental Pathology, University of Birmingham \\ F. C. Walker, Ch.M., F.R.C.S. \\ Lecturer in Surgery, University of Birmingham \\ From The Queen Elizabeth Hospital, Birmingham
}

Thomas (1874) and Lister (1899) first demonstrated histological abnormalities in the liver of patients with ulcerative colitis, and there has been a series of further reports (Elsom and Ferguson, 194I; Kimmelstiel, Large and Verner, 1952; Kleckner, Stauffer, Bargen and Dockerty, 1952; Boden, Rankin, Goulston and Morrow, 1959) describing a varying pattern of damage. In a series of 245 cases of ulcerative colitis coming to operation at this hospital, jaundice was a marked feature in 19, in two occurring before operation (both of whom died) and in the rest immediately after operation with the exception of three who developed the complication at a late stage and also suffered from cirrhosis. The Coomb's test was negative when performed and thus hæmolysis was an unlikely cause for the rise in serum bilirubin; it seems more likely that the hyperbilirubinæmia was the result of a deterioration in liver function. That a considerable degree of histological abnormality can occur in the liver before jaundice becomes manifest may be seen from Fig. I, a liver biopsy taken from a woman at a time when she was not jaundiced and whose serum bilirubin level was then only $1.8 \mathrm{mg} . / 100 \mathrm{ml}$; c clinical jaundice developed before she died Io days after operation.

In its clinical manifestations ulcerative colitis presents itself in two distinct forms: either as a chronic or recurrent diarrhoea in an individual who otherwise shows no marked general disorder save wasting, or as a severely toxic general disorder in addition. The deaths occurring in our series of operation cases are shown in Table I, together with the incidence of jaundice in the fatal cases. Of the non-jaundiced patients, causes of death included infection (7), intestinal obstruction (2), myocardial infarction $(\mathrm{I})$, pulmonary embolus $(\mathrm{I})$,

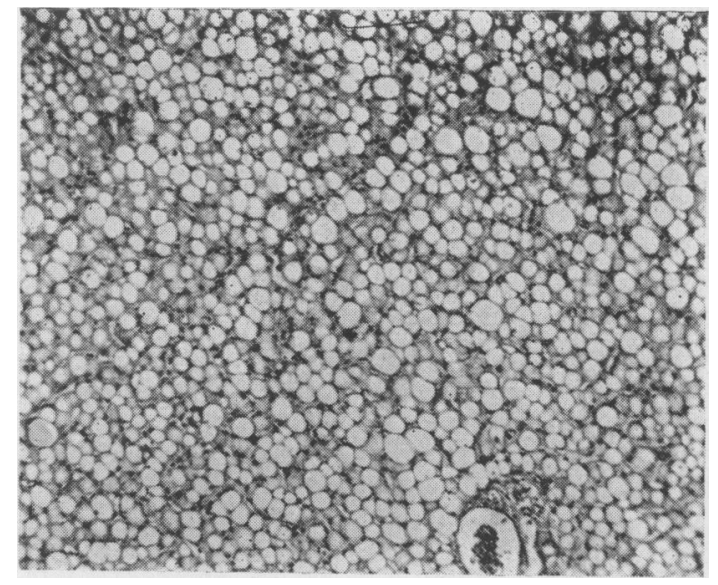

FIG. I

TABLE I

Mortality During the Immediate Post-operative Period in Patients Operated ON For Ulcerative Colitis

\begin{tabular}{c|c|c|c|c}
\hline & $\begin{array}{c}\text { Patients } \\
\text { operated } \\
\text { on }\end{array}$ & $\begin{array}{c}\text { With } \\
\text { jaundice }\end{array}$ & $\begin{array}{c}\text { Without } \\
\text { jaundice }\end{array}$ & Total \\
\hline Before 1956.. & 126 & 3 & 9 & 12 \\
\hline 1956 onwards & 120 & 7 & 7 & 14 \\
\hline
\end{tabular}

biochemical imbalance (2) and suprarenal failure (3). As technique has improved it has been possible to operate on more seriously ill patients, possibly explaining the increased incidence of jaundice in fatal cases; it may be that impairment of liver function contributed significantly to their death. Can it be, therefore, that the liver becomes 
damaged by leakage into the portal system of noxious substances either chemical or bacterial, thus causing a simple diarrhoic disorder to develop into the more general sickness? Or is the liver disorder simply a secondary manifestation associated with malnutrition? With these thoughts in mind certain investigations have been pursued at the Urited Birmingham Hospitals.

\section{The Portal Blood}

The situation in the portal blood was first investigated, since attention had been turned to this by the occurrence of deep jaundice (serum bilirubin $10.7 \mathrm{mg} . / 100 \mathrm{ml}$.) in one patient ushered in immediately after operation by rigors and pyrexia to $103^{\circ}$ to $104^{\circ}$, whose serum albumin was $3.2 \mathrm{~g}$. and globulin $2.7 \mathrm{~g} . / 100 \mathrm{ml}$. Jaundice had previously been seen to develop within 48 hours of operation; the rigors in this case seemed to suggest a bacterial cause and where else than from the infected bowel disturbed by operative manipulation? A pilot study was undertaken (Brooke and Slaney, 1958), revealing organisms to be present in the portal blood in four out of nine cases of ulcerative colitis and none of 10 in a control series of cases coming to laparotomy for causes other than ulcerative colitis. Ninety consecutive cases have now been sampled, revealing portal bacteræmia in 24 , the organisms being coliform, welchii, staphylococci and proteus. Two samples are taken, one before mobilization and one after; in the last 49 cases liver biopsy has been performed and in two, organisms identical with those in the portal blood recovered. The systemic blood has also been sampled; in none of the 24 were organisms grown from the peripheral circulation (this has now occurred in a subsequent case). No further control series have been undertaken here; the work of Orloff, Peskin and Ellis (1958) revealed no portal bacteræmia in IOI cases with conditions other than ulcerative colitis.

It is an odd fact that liver abscess and frank portal pyæmia do not occur in ulcerative colitis, though from half of those who developed jaundice organisms were recovered from the portal blood. The inference appears to be that the reticuloendothelial system within the liver can effectively deal with the organisms presented to it. Indeed, bacteria in the portal blood may only serve as an indicator of leak in the particulate or molecular sense; it is not unreasonable to imagine chemical constituents ordinarily contained within the bowel lumen proving toxic to the liver on escape through ulcers which permit the passage of bacteria into the portal system.

\section{Liver Function in Ulcerative Colitis}

The next step has been to establish the nature

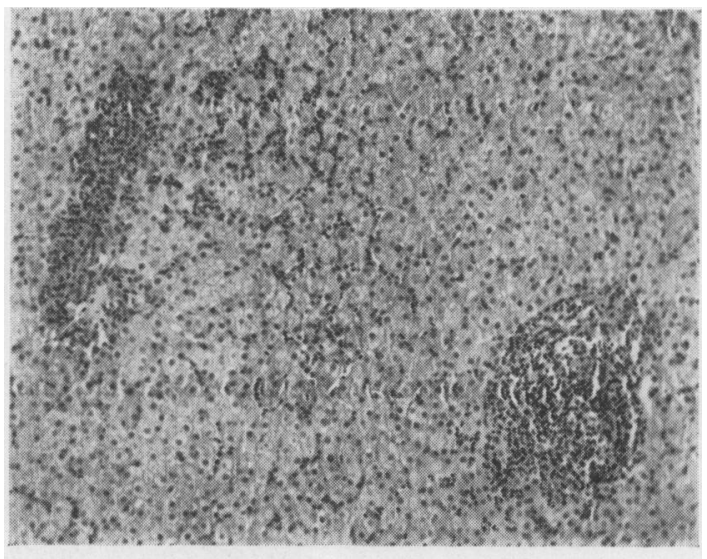

(a)

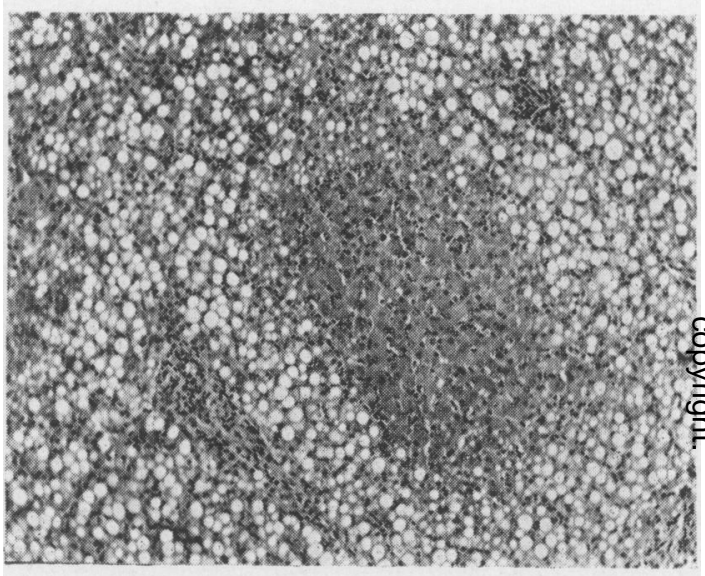

(b)

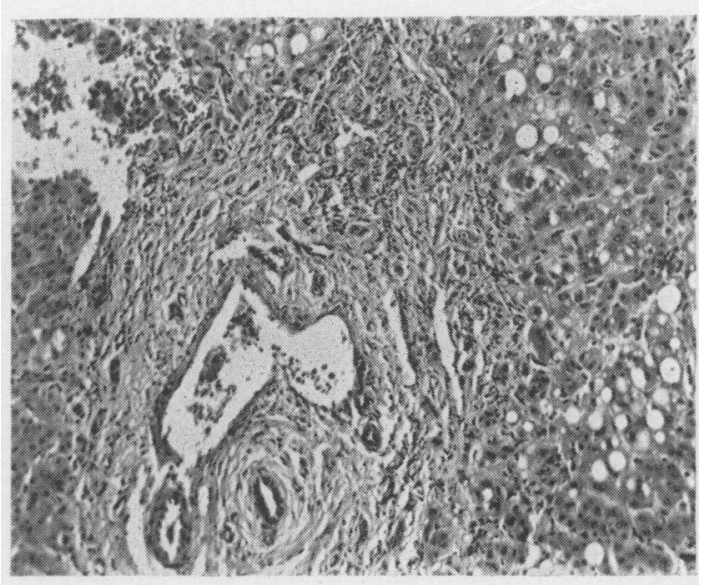

(c)

FI 3. 2.-(a) Periportal round-cell infiltration. (b) Periportal fatty degeneration. Note also some roundcell infiltration; it is common to find the two conditions in conjunction. (c) Cirrhosis-rare in ulcerative colitis. 
and incidence of liver damage and observe any possible correlation between this and the clinical state of the disease. Liver biopsy has been obtained from 49 consecutive cases coming to operation; significant abnormalities have been observed in 37 , and of these 18 were mild and 19 marked. These changes took three different forms (Fig. 2). Cirrhosis was uncommon, being seen in only three cases, while fatty infiltration and degeneration were most common and frequently associated with round-cell periportal infiltration. Though the fatty changes may simply reflect malnutrition, the round-cell mobilization is more suggestive of a reticulo-endothelial response to infection. Repair took place rapidly (Fig. 3); likewise the damage developed quickly (Fig. 4) and in this case the acute recrudescence had developed so recently as to cause doubt as to whether a nutritional factor could have been active.

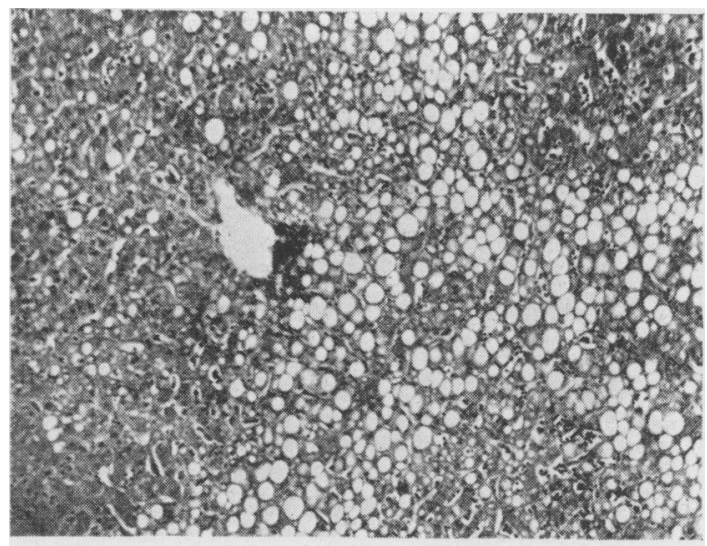

(a)

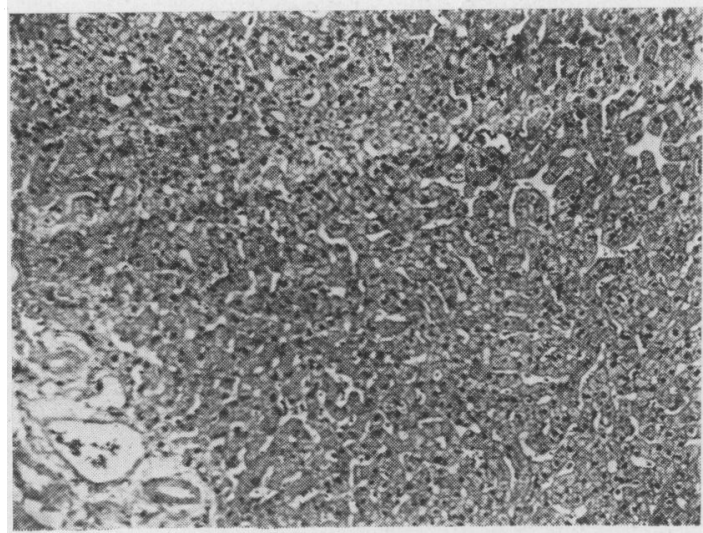

(b)

FIG. 3.-(a) Liver histology during acute phase at the time of primary colectomy. (b) State of liver three months later at the time of excision of the rectum; the patrent was then well.

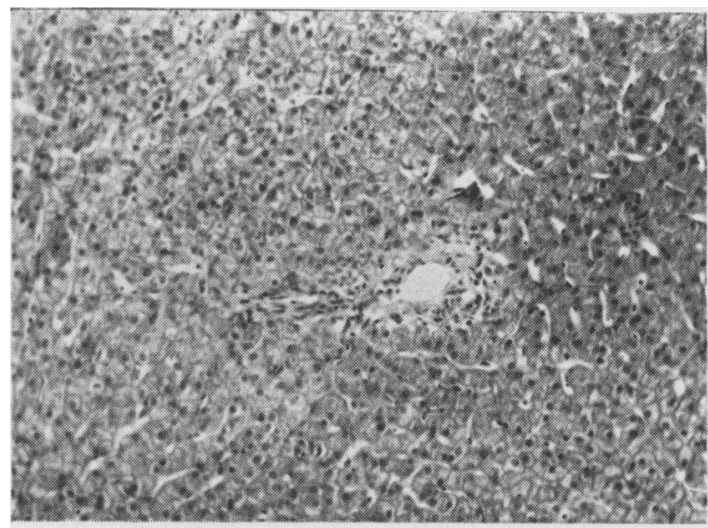

(a)

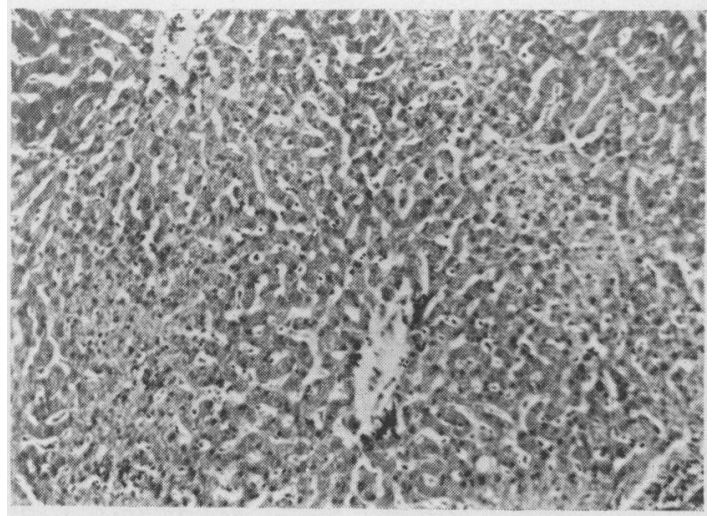

(b)

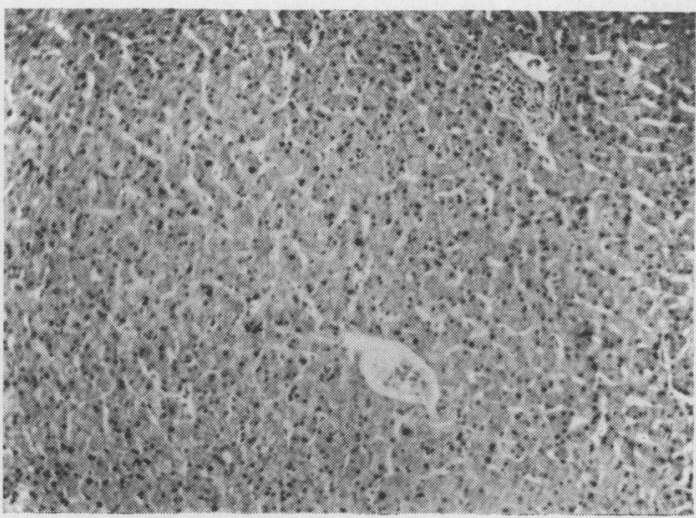

(c)

FIG. 4.-(a) Liver histology during remission. (b) Liver histology six months later during an acute exacerbation of two weeks' duration; primary colectomy was performed. (c) Liver histology six months after colectomy at the time of rectal excision when the patient was well. 
While direct correlation between degree of liver damage and severity of the disease is not possible, it can be said that severe damage has been common in the toxic cases and that in this group liver changes have never been insignificant.

Derangement in liver-cell function might be expected with the appearance of such an abnormal histological pattern and the elevated serum bilirubin concentrations described above are probably evidence of this. However, in spite of the accumulation of considerable information in the last 20 years on the biochemical processes occurring in the liver, assessment of the degree of impairment in hepatic function in man remains inexact owing to the variety of causes which affect the usual parameters of measurement. In this respect liver function may be assessed in the following ways:

Bilirubin: approximately half of the patients who are found at laparotomy to have portal bacteræmia also suffer from jaundice at some time during that particular hospital admission, whereas jaundice is uncommon in those with negative portal-blood cultures (Brooke, 1959). While this does not necessarily imply defective hepatocellular function, the absence of evidence of hæmolysis does suggest that the fault lies in the conjugation and excretion of bilirubin, i.e. in the liver and biliary tract.

Alkaline phosphatase and cholesterol: Elevation of serum alkaline phosphatase concentration has been observed, particularly in association with the histological pattern of bile casts and proliferation of bile ducts (Bargen, r953; Boden, Rankin, Goulston and Morrow, 1959) and it seems probable that this is another manifestation of the manner in which ulcerative colitis may affect liver function. Probably the best clinical evidence of this association is provided by Rankin, Boden, Goulston and Morrow (1959), who observed a reduction in serum alkaline phosphatase and an improvement in the histological picture following treatment with tetracycline for a few months.

Bromsulphthalein (BSP): moderate degrees of BSP retention have been described in approximately 10 to $20 \%$ of patients with more severe ulcerative colitis (Pollard and Block, I948; Bendandi, 1956), but Bendandi (1956) has pointed out that this test is affected by fever, anæmia and oligæmia; this degree of impairment of extraction of the dye is to be expected in this proportion of these patients and is not necessarily indicative of specific hepatic damage.

Portal-systemic encephalopathy, spider navi, liver failure and portal hypertension have not been described, except in association with cirrhosis. The incidence of cirrhosis is similar in patients with ulcerative colitis and in the population generally (Jones, Baggenstoss and Bargen, 195 I), so that the association of the two diseases is probably co- $\frac{\overrightarrow{0}}{7}$ incidental. Since the complications described 2 above are no more frequent than might be expected $\frac{3}{8}$ in a random sample of the population, liver damage $\varrho$ apparently does not reach the severity found in $\hookrightarrow$ either severe infective hepatitis or advanced $\vec{\sigma}$ cirrhosis.

Serum protein abnormalities: albumin is manu- 듬 factured exclusively by the liver (Peters, 1957); $\overline{\overline{0}}$ hence with sufficient substances available for syn- $\widehat{\Phi}$ thesis and the absence of either an increased catabolic rate or an abnormal loss from the body ${ }^{\infty}$ (e.g. nephrotic syndrome), its serum concentration $\vec{\circ}$ may be regarded as a satisfactory measure of liver $-\vec{\overrightarrow{ }}$ cell function. The origin of serum globulins, $\stackrel{\omega}{\sigma}$ however, is not clearly defined and Anker (1960)응 states that, whilst the majority are probably manu- 3 factured in the Kupffer cell, the remainder of the reticulo-endothelial system almost certainly con- -1 tributes with possibly other organs as well. Increasing the serum albumin concentration pro- iv duces no reduction in the total body $\gamma$-globulin in $c$ r patients with cirrhosis of the liver (Dykes, in press)을 and probably no decrease in either its rate of $\rightarrow$ synthesis or catabolism (work in progress); hence, $\vec{z}$ while observations on the concentrations of the separate serum protein fractions are valuable in $\vec{\varphi}$ their own right, the $\mathrm{A} / \mathrm{G}$ ratio is not, in this respecg very meaningful. Abnormalities in serum album or globulin concentrations in patients with ulcerfo tive colitis have been reported by many workers (Bockus, 1944; Ross and Swarts, 1948; Spellberg, Mosiman and Smith, 1950).

\section{Serum Protein Studies in Ulcerative Colitis}

Serum protein concentrations were measured by salt precipitation techniques in 46 of the 49 皮 patients described above in whom liver biopsy was performed at the time of operation. Assuming that the lower limit of the normal range for albumin is $3.4 \mathrm{~g} . / 100 \mathrm{ml}$. and the upper limit for 3 total globulin is $2.9 \mathrm{~g} . / 100 \mathrm{ml}$., then the results indicated that 24 patients $(52 \%)$ showed both low albumin and raised globulin concentrations, nine 0 $(20 \%)$ normal albumin and raised globulin, five (11\%) had low albumin and normal globulin concentrations and eight $(17 \%)$ showed normal values.

Analysis of the increase in total globulin concentration by paper electrophoresis has revealed the major increase to occur in $\alpha_{1}$ and $\alpha_{2}$ globulin fractions (Spellberg, Mosiman and Smith, 1950; Bendandi, 1956), whereas the $\gamma$-globulin concentration is usually normal. This is surprising $\stackrel{\mathscr{P}}{\rightarrow}$ in view of the demonstration of circulating anticolon antibodies by Broberger and Perlmann (1959) and the implication that the disease involves an immune reaction (Lancet, 1959); attempts by 
TABLE 2

Data Obtained from Four Patients with Ulcerative Colitis at the Queen Elizabeth Hospital (i-4) and Three (5-7) REPORTEd By STEINFEld et al. (1960)

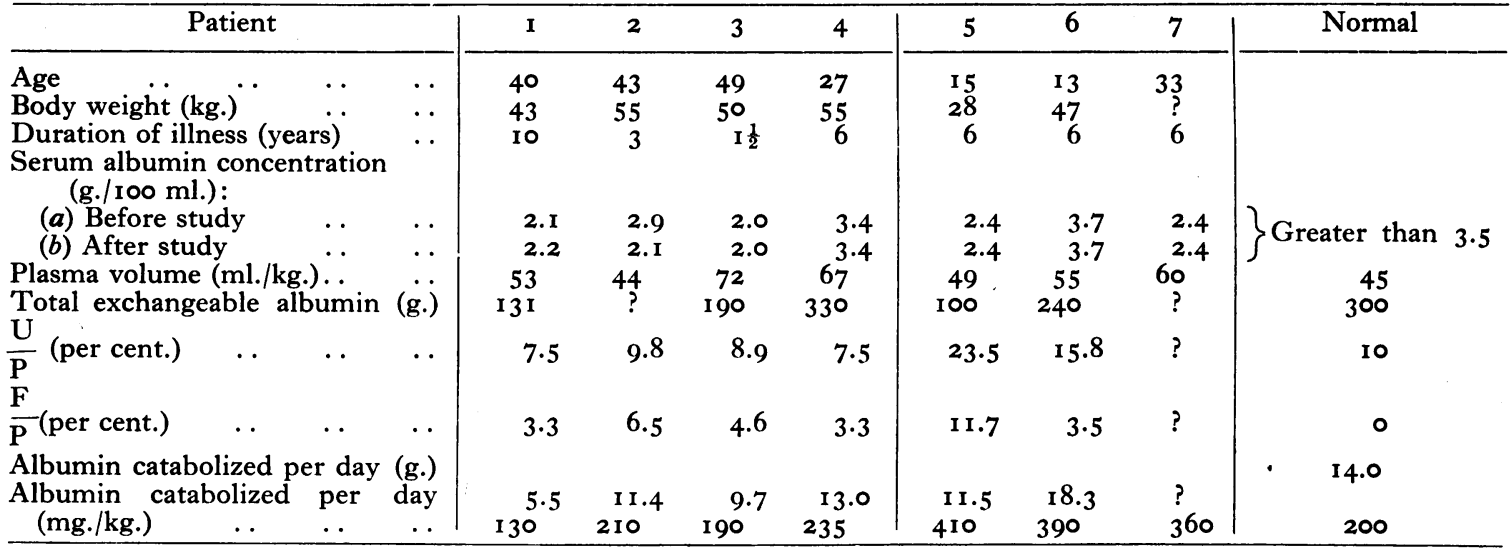

$\mathrm{U}$-activity of $\mathrm{I}^{131}$-labelled albumin in $24-\mathrm{hr}$. specimen of urine.

F- ,", , , , , , , , fæces.

P-total' activity of plasma.

F. C. Walker and J. G. Gray at this centre to confirm these findings, however, have been unsuccessful. Evidence given below, however, reveals considerable protein 'leak' from the colonic mucosa, making serum concentrations misleading in assessing rates of synthesis. The inverse relationship between the total serum globulin concentration and the severity of the disease shown above is consistent with colonic leakage of protein, suggesting that, while globulin synthesis is greater than normal, abnormal loss prevents the serum concentration from reaching its expected level, particularly in those most severely affected. The significance of the increased $\alpha$-globulin fraction is not clear, but it is possible that, as in the nephrotic syndrome (Hardwicke and Squire, 1955), it results from a selective leak of smaller molecular weight proteins with accumulation in the serum of the larger protein molecules, e.g. $\alpha_{2}$-glycoprotein, $\beta$-lipoprotein.

The low serum albumin concentration seen in this disease has been variously ascribed to malnutrition following anorexia and malabsorption (Zetzel, Banks and Sagall, 1942), to impairment of liver function (Popper and Schaffner, 1957), or to protein leak from the abnormal colonic mucosa (Welch, Adams and Wakefield, I937). Some minor change in the speed of passage of food through the gut has been reported (Elsom, Dickey and Chornock, 1942), and the reduction in appetite in more severely ill patients could also affect the rate of synthesis by decreasing the supply of albumin precursors. A fall in serum albumin concentration may, however, occur rapidly in an exacerbation of the disease, whereas deliberate de- privation of protein in normal subjects has shown only slight and slowly developing changes in serum protein patterns (Keys, Taylor, Mickelsen and Henschel, 1946). We have studied albumin metabolism and found, however, that in most of these patients the rate of synthesis is not significantly impaired and therefore deficient absorption and liver-cell function must contribute little, if at all, to the subnormal serum concentration-work now confirmed by a recent publication by Steinfeld, Davidson, Gordon and Greene (1960). Albumin labelled with $\mathrm{I}^{131}$ (McFarlane, 1956) was injected intravenously, the plasma disappearance rate determined and the amount of activity in 24-hour collections of urine and fæces measured and expressed as a percentage of the total activity of the plasma $(\mathrm{U} / \mathrm{P}$ and $\mathrm{F} / \mathrm{P}$ respectively). These two values are then a measure of the catabolic rate of albumin and indicate the route of excretion of the whole protein or its degradation products.

Comparison is made in Table 2 between our data and those presented by Steinfeld et al. (1960) and demonstrates the following points:

There was a considerable reduction in serum albumin concentration (measured in our patients by paper electrophoresis (Hardwicke, 1954)) and also in the total exchangeable albumin pool, determined from the ratio of total body radioactivity to total plasma activity once even distribution had occurred between the different body compartments (usually at eight days).

Fæcal excretion of radioactivity was abnormal in every instance, reaching a maximum value representing $11.7 \%$ of circulating albumin (patient 5 , Steinfeld $e t$ al. series). The radioactive content of 
the urine varied considerably between the two series; whereas our patients excreted in the urine an average of $8.4 \%$ of plasma activity per day, those of Steinfeld et al. passed approximately $20 \%$.

It is difficult to explain this difference provided the quality of the protein was similar in each series. A major omission in the collection of urine in our series would also explain the discrepancy, but we do not believe this occurred. Holman, Nickel and Sleisenger (1959) have demonstrated that albumin inside the lumen of the small intestine is rapidly catabolized; the products are then reabsorbed into the blood stream and excreted in the urine (Borgström, Dahlqvist, Lundh and Sjövall, I 957; Lavik, Matthews, Buckaloo, Lemm, Spector and Friedell 1952). Thus urinary radioactivity in the patients studied.represents the normal catabolic rate plus an amount which depends upon the degree of proteolysis of the exuded serum albumin. We have also shown that the radioactivity of $I^{131}$-labelled albumin introduced into the rectum of a normal individual as a retention enema results in the return of only $10 \%$ of the administered dose in the fæces I 2 hours later, the remainder appearing in the urine during the succeeding two days: no labelled protein was located in the plasma. Whether this degree of proteolysis and reabsorption of catabolic products occurred to any extent in these patients must have depended upon the enzymic content of the fæces and the speed of transit through the large bowel. Investigation in two patients has demonstrated that at least $70 \%$ of fæcal radioactivity is not protein bound, and so the rapidity of transit of fæces through the large bowel must be responsible for the failure of the colonic mucosa to reabsorb the released radioactivity. A longer transit time would enable more free iodide and labelled amino acid to be absorbed, thus increasing relatively the urinary excretion; it is possible that a difference between the patterns of disease studied by Steinfeld et al. and ourselves would thus explain the difference between the two series.

The total quantity of albumin catabolized daily is normal in most cases with two exceptions, one (patient 6) being greater and one (patient $\mathrm{I}$ ) being less than normal. Steinfeld et al. expressed their total catabolic rates as $\mathrm{g}$. albumin per $\mathrm{kg}$. body weight at the time of study, a practice which may be misleading, since their patients had lost considerable amounts of weight; expressed as g. albumin per kg. body weight when well, those catabolic rates might then lie within the normal range. The findings of constant body weights and serum albumin concentrations imply that the total exchangeable albumin pool is approximately constant; the total catabolic rate measured is therefore an approximation for the rate of albumin synthesis in all cases apart from patient 2 (in whom a significant fall occurred in serum concentration during the period of study). The mean rate of synthesis in both groups is $11.6 \mathrm{~g}$./day, a value $\cong$ which lies within the normal range (Berson, Yalow, Schreiber and Post, 1953). The rate of synthesis $\overrightarrow{\bar{c}}$ was apparently a little greater than normal in one $\overline{0}$ (patient 5), and considerably reduced in another 0 (patient I), but these are not changes of sufficient $\overline{\frac{\bar{m}}{}}$. magnitude to be significant. It may therefore $\Phi$ be concluded that the rate of albumin synthesis in this group of patients is within normal limits and कs provides no additional evidence of an impairment $\vec{\circ}$ of liver-cell function.

The other plasma protein changes reported in ulcerative colitis, when considered against this ${ }_{0}$ background, do not add further to the picture. 3 Serum prothrombin activity has been reported by Page and Bercovitz (1942) to be reduced, but the is effect of injections of vitamin $\mathrm{K}$ was not studied, nor colonic leakage considered. Raised fibrinogen i levels recorded by the same authors are presumably on related to the elevated globulin concentrations, as $\triangle$ are the abnormal empirical flocculation tests (Pollard and Block, 1948). Further investigation along these lines is likely to reflect the pathophysiology of the diseased colon rather than $\vec{\oplus}$ abnormalities of hepato-cellular function.

\section{Conclusion}

In conclusion, therefore, the evidence of damage

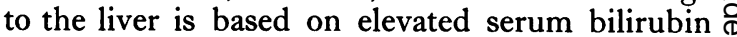
and alkaline phosphatase concentrations and $\varrho$ histological abnormalities which are usually reversible. There is no other convincing evidence of an interference with the metabolic processes occurring in the liver, and all other abnormalities of the so-called liver function tests have very adequate explanations quite unrelated to hepatic pathology. There appears to be good agreement 3 between the degree of functional and histological $\delta$ damage to the liver in patients with ulcerative colitis. Neither severe physiological derangements, such as deficient protein synthesis and portal-sytsemic encephalopathy, nor irreversible pathology, e.g., cirrhosis and acute atrophy, appear to be sequelæ of ulcerative colitis. Elevated serum os bilirubin concentrations and serum alkaline phos- N phatase are less sinister findings and associated N with portal bacteræmia, round-cell infiltration in $\sigma$ the liver and biliary stasis; although not in themselves implying impending hepatic failure, they probably materially contribute to a deteriorating $\stackrel{\oplus}{\rightarrow}$ clinical condition. The low serum albumin concentration is the result of colonic leakage of protein $\overline{0}$ into the lumen of the bowel and is not the result of $\mathbb{D}$ impaired hepatic synthesis. 


\section{REFERENCES}

Anker, H. S. (1960): 'The Plasma Proteins', Vol. 2. New York: Academic Press.

Bargen, J. A. (1953): Disease of the Liver Associated with Ulcerative Colitis, Ann. intern. Med., $39,285$.

BENDANDI, A. (1956): Liver Function in Ulcerative Colitis, Gastroenterologia (Basel), 86, 658.

Berson, S. A., Yalow, R. S., Schreiber, S. S., and Post, J. (1953): Tracer Experiments with I ${ }^{131}$ Labelled Human Serum Albumin: Distribution and Degradation Studies, $\mathcal{F}$. clin. Invest., 32, 746.

Bockus, H. L. (1946): ' Gastroenterology', Vol. 3. Philadelphia: J. B. Saunders.

Boden, R. W., Rankin, J. G., Goulston, S. J. M., and Morrow, A. W. (1959): The Liver in Ulcerative Colitis, Lancet, ii, 245.

Borgström, B., DAhlqvist, A., Lundh, G., and Sjövall, J. (r957): Studies of Intestinal Digestion and Absorption in the Human, $\mathcal{F}$. clin. Invest., 36, 1521 .

Broberger, O., and Perlmann, P. (1959): Autoantibodies in Human Ulcerative Colitis, f. exp. Med., rro, 657.

Brooke, B. N. (1959): Granulomatous Diseases of the Intestine, Lancet, ii, 745.

, and Slaney, G. (1958): Portal Bacteræmia in Ulcerative Colitis, Ibid., i, 1206.

Elsom, K. A., Dickey, F. G., and Chornock, F. W. (r942): Functional Disturbances of the Small Intestine in Chronic Idiopathic Ulcerative Colitis, Amer. F. dig. Dis., 9, 74.

- - and Ferguson, L. K. (194I): An Appraisal of the Medical Versus the Surgical Treatment of Idiopathic Ulcerative Colitis, Amer. F. med. Sci., 202, 59.

Hardwicke, J. (1954): Estimation of Serum Proteins by Electrophoresis on Filter Paper, Biochem. F., 57, 166.

- , and SQuire, J. R. (1955): The Relationship Between Plasma Albumin Concentration and Protein Excretion in Patients with Proteineuria, Clin. Sci., I4, 509.

Holman, H., Nickel, W. F., and Sleisenger, M. H. (1959): Hypoproteinæmia Antedating Intestinal Lesions and Possibly Due to Excessive Serum Protein Loss into the Intestine, Amer. Y. Med., 27, 963.

Jones, G. W., Baggenstoss, A. H., and BARgen, J. A. (195I): Hepatic Lesions and Dysfunction Associated with Chronic Ulcerative Colitis, Amer. F. med. Sci., 221, 279.

Keys, A., Taylor, H. L., Mickelsen, O., and Henschel, A. (1946): Famine CEdema and the Mechanism of its Formation, Science, ro3, 669.

Kimmelstiel, P., Large, H. L., and Verner, H. D. (1952): Liver Damage in Ulcerative Colitis, Amer. F. Path., $28,259$.

Kleckner, M. S., Stauffer, M. H., Bargen, J. A., and Dockerty, M. B. (1952): Hepatic Lesions in the Living Patient with Chronic Ulcerative Colitis as Demonstrated by Needle Biopsy, Gastroenterology, $22,13$.

Lancet (1959): Antibodies to Colon in Ulcerative Colitis, ii, Ir33.

Lavik, P. S., Matthews, L. W., Buckaloo, G. W., Lemm, F. J., Spector, S., and Friedell, H. L. (i952): Use of $I^{131}$ Labelled Protein in the Study of Protein Digestion and Absorption in Children with and without Cystic Fibrosis in the Pancreas, Pediátrics (N.Y.), ro, 667.

Lister, T. D. (1899): A Specimen of Diffuse Ulcerative Colitis with Secondary Acute Interstitial Hepatitis, Trans. path. Soc. Lond., 50, I 30.

McFarlane, A. S. (1956): Labelling of Plasma Proteins with Radioactive Iodine, Biochem. Y., 62, I 35.

Orloff, M. J., Peskin, G. W., and Ellis, H. L. (1958): A Bacteriologic Study of Human Portal Blood: Implications Regarding Hepatic Ischæmia, Ann. Surg., 148, 738.

Page, R. C., and Bercovitz, Z. (1942): Prothrombin and Fibrinogen Studies in Chronic Ulcerative Colitis, Amer. F. dig. Dis., 9, 419.

Petres, T., JR. (1957): A Serum Albumin Precursor in Cytoplasmic Particles, f. biol. Chem., $229,659$.

Pollard, H. M., and Block, M. (1948): Association of Hepatic Insufficiency in Chronic Ulcerative Colitis, Arch. intern. Med., 82, 159.

Popper, H., and SchaffNer, F. (1957): 'Liver: Structure and Function'. New York: McGraw Hill Book Co.

Rankin, J. G., Boden, R. W., Goulston, S. J. M., and Morrow, A. W. (1959): The Liver in Ulcerative Colitis, Lancet, ii, 1110.

Ross, J. R., and Swarts, J. M. (1948): Hepatic Dysfunction and Cirrhosis in Chronic Ulcerative Colitis, Gastroenterology, ro, 81 .

Spellberg, M. A., Mosiman, W. D., and Smith, L. C. (1950): Electrophoretic Studies of Plasma Proteins in Ulcerative Colitis, F. Lab. clin. Med., 36, 991 .

Steinfeld, J. L., Davidson, J. D., Gordon, R. S., and Greene, F. E. (1960): The Mechanism of Hypoproteinæmia in Patients with Regional Enteritis and Ulcerative Colitis, Amer. F. Med., 29, 405.

Thomas, G. H. (1874): Ulceration of the Colon with Enlarged Fatty Liver, Trans. path. Soc. Philadelphia, $4,87$.

Walker, F. C., and Gray, J. G.: Personal communication.

Welch, C. S., Adams, M., and WAkefield, E. G. (1937): Metabolic Studies in Chronic Ulcerative Colitis, f. clin. Invest ., I6, 16r.

Zetzel, L., Banks, B. M., and Sagall, E. (1942): Intestinal Absorption of an Amino-Acid Mixture in Patients with Chronic Idiopathic Ulcerative Colitis and Enterocolitis, Amer. $\mathcal{Y}$. dig. Dis., 9, 350. 